\title{
Legal Construction on Training Ship Management Belongs To Human Resources Development Of Transportation (BPSDMP) Based On Dignity Justice Value
}

\author{
Wahyu Wibisono ${ }^{1}$
}

\begin{abstract}
President of the Republic of Indonesia, Joko Widodo stressed that in the coming year human resource development is a key priority in the government program (Nawacita) and focused on three things; positive character development, improvement of access, quality of education, development and match the link between industry and vocational education, one of them by adding a nautical school educational facilities with their training ship. Six (6) training ship construction started in December 2015 and completed in stages over two years to finance multi-year state budget until 2019. And finally Human Resources Development Of Transportation (BPSDMP) Ministry of Transportation in coordination with the Minister of maritime has ordered six (6) units training ship cadets that each measure approximately 1200 GT (Gross Tonnage) with a capacity of 300 people, which is built in harbor and the domestic industry by PT Steadfast Marine Pontianak. Coordinating Minister of Maritime also said that with the training ship would be easier for BPSDM to improve the quality of education Midshipman cruise who were taking education time official the country especially in the field of shipping, including also can help private schools and shipping academy that did not have a training ship for come to enjoy it. So the hope is able to bring high quality graduates and proud when recruited at the national and international shipping companies.

Keywords: Legal Construction; Training ship Management; Dignity Justice.
\end{abstract}

\section{Introduction}

Joko Widodo stressed that in the coming year human resource development is a key priority in the government program and focused on three things; positive character development, improvement of access, quality of education, development and match the link between industry and vocational education, one of them by adding a nautical school educational facilities with their training ship ${ }^{2}$.

Coordinating Minister of Maritime also said that with the training ship would be easier for BPSDM to improve the quality of education Midshipman cruise who were taking education time official the country especially in the field of shipping, including also can help schools and academys private shipping that did not have a training ship for come to enjoy it. So the hope is able to bring high quality graduates and proud when recruited at the national and international shipping companies ${ }^{3}$.

\footnotetext{
${ }^{1}$ Lecturer of Merchant Marine Polytechinc of West Sumatra (Poltekpel Sumatra) and Student Doctor of Law, Sultan Agung Islamic University in Semarang, email: wahyuwibisono15@gmail.com.

${ }^{2}$ Amir, HT., 2007. Pengembangan Program Pelatihan Kerja pada Balai Latihan Kerja Instruktur dan Pengembangan Surabaya. Jurnal Balitbang Jawa timur, cakrawala the first edition, month 6, p. 17

${ }^{3}$ Christian K, 2008. Analisa Revitalisasi Balai Latihan Kerja.
} 
And finally Human Resources Development Of Transportation (BPSDMP) Ministry of Transportation in coordination with the Minister of maritime has ordered six (6) units training ship cadets that each measure approximately 1200 GT (Gross Tonnage) with a capacity of 300 people, which is built in harbor and the domestic industry by PT Steadfast Marine Pontianak. The training ship is intended to school sailing under the auspices of the Human Resources Development Agency (BPSDMP) Ministry of Transportation*.

\section{Research Methods}

This research is the qualitative research with Socio-Legal approach, which is based on legal norms and legal enforceability of existing theory by reviewing the juridical law from the standpoint of sociology as an Interpretation Understanding.

\section{Results And Discussion}

\subsection{Training ship and Regulation}

During this cruise school cadets faced problems difficult to practice or climb aboard quickly because of limited training ship. Training ship is a vessel used to train students who want to become a sailor used as laboratory practice. In addition to the training sailing training ship also versatile, ranging from teaching about oceanography, biology, marine science, and physics; until the construction of character ${ }^{5}$. However, there has been no regulation training ship and thus require a clear legal construction.

Legal construction ${ }^{6}$ is the establishment of the law by law enforcement officials to fill the legal vacuum that exists in the system caused Act because the legislation in static / fixed, while the society is always changing / dynamic, so it will be a legal vacuum in society ${ }^{7}$.

Six (6) training ship construction started in December 2015 and completed in stages over two years to finance multi-year state budget until 2019. The BPSDM head of the Ministry of Transportation, Dr. Wahju Satrio Utomo explained that the training ship bookings appropriate employment contract then all the training ship to be sent to the government until the end of 2017, with details coming month of March-April two ships, two ships again in September and December two remaining

\footnotetext{
${ }^{4}$ Erlinda, 2010. Strategi Pengembangan Balai Latihan Kerja Sumatera Barat. Tesis Pasca Sarjana Universitas Andalas, p. 31

${ }^{5}$ Modul Pelatihan Berbasis Kompetensi (2009), Menentukan Tujuan, Prasyarat, dan Materi Pelatihan, Jakarta: Kemenakertrans RI. Lihat juga Modul Pelatihan Berbasis Kompetensi (2009), Merancang Pembuatan Sarana Pendukung Pembelajaran, Jakarta: Kemenakertrans RI

${ }^{6} \mathrm{http}$ ://dasardasarilmuhukum.blogspot.com/2016/09/konstruksi-hukum-1.html

${ }^{7}$ Ibid.
} 
ships $^{8}$. The training ship built of steel with fully welded, two propellers, and is powered by two diesel engines. The main measure vessel length along the entire length of 63 meters with a straight line 59 meters, 12 meters wide, 4 meters high and 2.8 meters water depth requirement. The ship has 115 tons of the fuel tank and 175 tons of fresh water tank. The vessel has a minimum speed of 12 knots with a maximum power $2 \times 1000 \mathrm{hp}^{9}$, Measuring 1,200 GT vessel with the type multipurposes or can be used to transport cadets practice (Sea Project), carrying passengers and cargo carrying. The capacity of the ship can accommodate about 21 people crew, two passengers VVIP, 10 instructors, 100 cadets / midshipmen, and 100 passengers ${ }^{10}$.

In addition there are four (4) Boat Train that has passed the test or Sea Trial as Training Ship (KL) Bung Tomo belongs Poltekpel Surabaya has done maiden voyage on February 3, 2018 and takes about two days. The maiden voyage started from the shipyard PT Steadfast Marine in Pontianak-Kalimantan and arrived at the Port of Tanjung Perak on February 8, 2018. Three Training ship have also been launched and set sail first to the location of each school is owned BP2IP Malahayati Admiral KL Malahayati Aceh on December 26, 2017 to the Port Malahayati Aceh and KL Mohammad Husni Thamrin belongs to the School of Sailing (STIP) in Jakarta on December 29, 2017 to the Port of Tanjung Priok, and KL Frans Kaisiepo belonging to the Port of Sorong, BP2IP Sorong on February 2, 201811.

\subsection{Human Resources Development Agency of Transportation (BPSDMP) Provision Policy of Training ship for Sea Transportation School}

Head of BPSDMP, Djoko Sasono, explaining the construction of six (6) Training ship is part of the Strengthening the Character Education (KDP), namely industrial character. He explained that the function of training ship is a place of education, training, modeling and simulation in the sea and as a classroom for education process and teaching form and develop and improve the knowledge, skills, understanding and experience and attitude in a clump of science and technology commercial shipping ${ }^{12}$.

Training ship management entitlements to several schools / academys particular voyage is expected to take advantage of these ships to the educational needs of both institutional and inter-institutional nature, the more income generation. Still, the Training ship ownership remain the property of the Ministry

\footnotetext{
${ }^{8}$ Amir, Ibid., p. 17

${ }^{9}$ Nofi Erni,Iphov Kumala Sriwana, Debby Karisa (2013) “Peningkatan Kualitas Jasa Pelayanan dengan Metode Servqual dan Quality Function Deployment”. Journal Ilmiah Teknik Industri,Vol.1:59-66

${ }^{10}$ Hamalik, Oemar Prof.Dr (1993). Sistem dan Pengembangan Kurikulum Lembaga Pendidikan dan Pelatihan, Bandung, Trigenda Karya.

${ }^{11}$ Hamalik, Oemar. 2008. Perencanaan Pengajaran Berdasarkan Pendekatan Sistem. Jakarta: Bumi Aksara, p. 96

${ }^{12}$ Christian K, Ibid.
} 
of Transportation. And maritime transportation minister explained that the development and supply of six training ship also give private schools the opportunity maritime field to be able to use the training ship including practice facilities in it. With the training ship would be more easily included to assist private schools and academy, who had no training ship. But in fact these ships dominated and only focused on six nautical school MoT is BP2IP Malahayati Aceh, STIP Jakarta, Poltekpel Surabaya, PIP Makassar, BP2IP South Minahasa, and BP2IP Sorong in West Papua, which resulted in the school / academy other shipping both public and private sector can not use it as a means of practice and exercise. This is due to lack of regulatory management training ship that has been provided by the Ministry of Transportation. Of course the above should be a concern for the Ministry of Transportation and BPSMP especially also for the government to work together with relevant institutions to formulate and develop rules of governance training ship for school / academy in Indonesia. Thus, social jealousy between institutions could afford to justice and felt in all school / academy in Indonesia.

In addition to problems of decision-making on management training ship for school / academy as an educational institution that prepares candidates for sailors, of course, the quality of education of cadets to the parties concerned, especially the education in the field of port greatly affect the success and the Maritime Safety. Making decisions on management training ship for school / academy became one of the interesting things to be discussed and be examined by factors of quality improvement / quality of education for midshipmen cruise itself 13 ,

Coordinating Minister of Maritime, Luhut Binsar Panjaitan as inspector of the ceremony said that the development of Human Resources (HR) is a priority for the President of the Republic of Indonesia. It was a major concern that the current MoT continue to foster and develop a training institution in BPSDMP ${ }^{14}$. MoT is also very focused on a program to provide training ship for cadets in the school / academy to improve human resources for prospective seafarers. Because with one support availability of the training ship at sea sector is expected to boast the country of Indonesia, for three-level on sea transport graduates (ANT / ATT III) average has been in demand by national shipping company and international shipping.

The presence of six training ship as the Ministry of Transportation supports the efforts of the transport sector Nawacita determined by the President Joko Widodo and embodiment MoT work focus in 2016 to improve transportation

\footnotetext{
${ }^{13}$ Ibid.

${ }^{14}$ Modul Pelatihan Berbasis Kompetensi, Loc.Cit.
} 
safety by improving the quality of Human Resources Development of Transportation in Indonesia 15 .

\subsection{Legal Construction On Training Ship Management Belongs To Human Resources Development Of Transportation (BPSDMP) Based On Dignity Justice Value}

As for the proposed reconstruction of the government regarding the management and policies of the training ship at least as follows:

\begin{tabular}{|c|c|c|c|}
\hline No & $\begin{array}{c}\text { Proposed } \\
\text { Regulations }\end{array}$ & Article Content & Information \\
\hline 1 & $\begin{array}{c}\text { Part I } \\
\text { General } \\
\text { Requirements }\end{array}$ & $\begin{array}{l}\text { Ship, Ship of State, the country } \\
\text { training ship, skipper, crew boats, } \\
\text { National Marine Transport Company, } \\
\text { Route, Ministry of Communications, } \\
\text { Director General of Sea } \\
\text { Transportation and Head of Human } \\
\text { Resources Development of } \\
\text { Transportation }\end{array}$ & $\begin{array}{l}\text { Explanation } \\
\text { understanding and } \\
\text { working areas }\end{array}$ \\
\hline 2 & $\begin{array}{c}\text { Chapter Ii } \\
\text { Training Ship } \\
\text { Organization }\end{array}$ & $\begin{array}{l}\text { - The arrangement of the training } \\
\text { ship through the mechanism: a. } \\
\text { regular training assignment; b. } \\
\text { certain special assignment; } \\
\text { - } \text { Improving the competence of } \\
\text { seafarers or prospective } \\
\text { mariners using training ship. }\end{array}$ & $\begin{array}{l}\text { UPT implementation is } \\
\text { done by the owner in } \\
\text { order to: } \\
\text { - } \quad \text { Transport New Year; } \\
\text { - } \quad \text { Transport Religious } \\
\text { great day; } \\
\text { - Disaster management; } \\
\text { - } \quad \text { Operation Search and } \\
\text { Rescue; } \\
\text { - Other government } \\
\text { duties. }\end{array}$ \\
\hline 3 & $\begin{array}{l}\text { Chapter Iii } \\
\text { Financing }\end{array}$ & $\begin{array}{l}\text { 1) The components of operating } \\
\text { expenses: } \\
\text { - } \text { Fuel and fresh water } \\
\text { - } \text { Insurance crew } \\
\text { - } \text { boat insurance } \\
\text { - } \quad \text { Cost assignment crew } \\
-\quad \text { Logistic crew and other } \\
\quad \text { personnel }\end{array}$ & $\begin{array}{l}\text { Financing training ship } \\
\text { includes components: } a \text {. } \\
\text { ship operations cost; } b \text {. } \\
\text { upkeep and maintenance } \\
\text { of the ship cost. }\end{array}$ \\
\hline
\end{tabular}

15 Parasuraman, A., Valaire Zeithaml, and Leonard Berry, 1991, "Refinement and Reassesment of The SERVQUAL Scale”. Journal of Retailling. Vol. 67. No. 4 


\begin{tabular}{|c|c|c|c|c|c|}
\hline & & \multicolumn{3}{|c|}{$\begin{array}{ll}\text { - } & \text { ship docking } \\
\text { - } & \text { Unloading or embarkation/ } \\
\text { - } & \text { disembarcation } \\
\text { - } & \text { Learning on board } \\
\text { - } & \text { Other vessel operating } \\
\text { 2) The components of the cost of } \\
\text { maintenance and upkeep: } \\
\text { - The burden of care daily vessel } \\
\text { conducted in order to maintain } \\
\text { maritime standart, service and } \\
\text { comfort during vessel operation; } \\
\text { and } \\
\text { The cost of repairs in order to } \\
\text { restore the ship to remain } \\
\text { seaworthy vessel } \\
\text { The annual maintenance burden } \\
\text { and docking are conducted } \\
\text { periodically in order to maintain } \\
\text { ship in maritime standart. }\end{array}$} & \\
\hline 4 & $\begin{array}{c}\text { Chapter Iv } \\
\text { Learning Activity } \\
\text { Performance } \\
\text { Standard } \\
\text { Commercial } \\
\text { Vessel Train }\end{array}$ & $\begin{array}{l}\text { Each Unit Tra } \\
\text { Commerce Tr } \\
\text { to have and ir } \\
\text { Assurance Sy } \\
\text { Management }\end{array}$ & $\begin{array}{l}\text { ing } \\
\text { ns S } \\
\text { olem } \\
\text { em S } \\
\text { sten }\end{array}$ & $\begin{array}{l}\text { las the } \\
\text { e required } \\
\text { uality }\end{array}$ & $\begin{array}{l}\text { In the application referred } \\
\text { to in paragraph (1), the } \\
\text { ship of state minimum } \\
\text { training required to have } \\
\text { the following documents: } \\
\text { SOP, Bridge Procedure } \\
\text { Manual, SOLAS Training } \\
\text { Manual, Engine Procedure } \\
\text { Manual, Cargo Securing } \\
\text { Manual, }\end{array}$ \\
\hline 5 & $\begin{array}{l}\text { Chapter V } \\
\text { Manning }\end{array}$ & $\begin{array}{l}\text { Capten } \\
\text { Mualim I } \\
\text { Mualim II } \\
\text { Mualim III } \\
\text { Head of Engir } \\
\text { Machinist II } \\
\text { Machinist III }\end{array}$ & $\begin{array}{c}1 \\
1 \\
1 \\
1 \\
\text { Roo }\end{array}$ & $\begin{array}{l}\text { ANT II } \\
\text { ANT II } \\
\text { ANT III } \\
\text { ANT III } \\
\text { M) } 1 \text { ATT II } \\
\text { ATT II } \\
\text { ATT III }\end{array}$ & $\begin{array}{l}\text { All Crew, educators as } \\
\text { well as education and } \\
\text { cadets who were on } \\
\text { board the train shall } \\
\text { conduct safety } \\
\text { familiarization } \\
\text { - Educators as well as } \\
\text { education and training } \\
\text { cadets onboard must }\end{array}$ \\
\hline
\end{tabular}




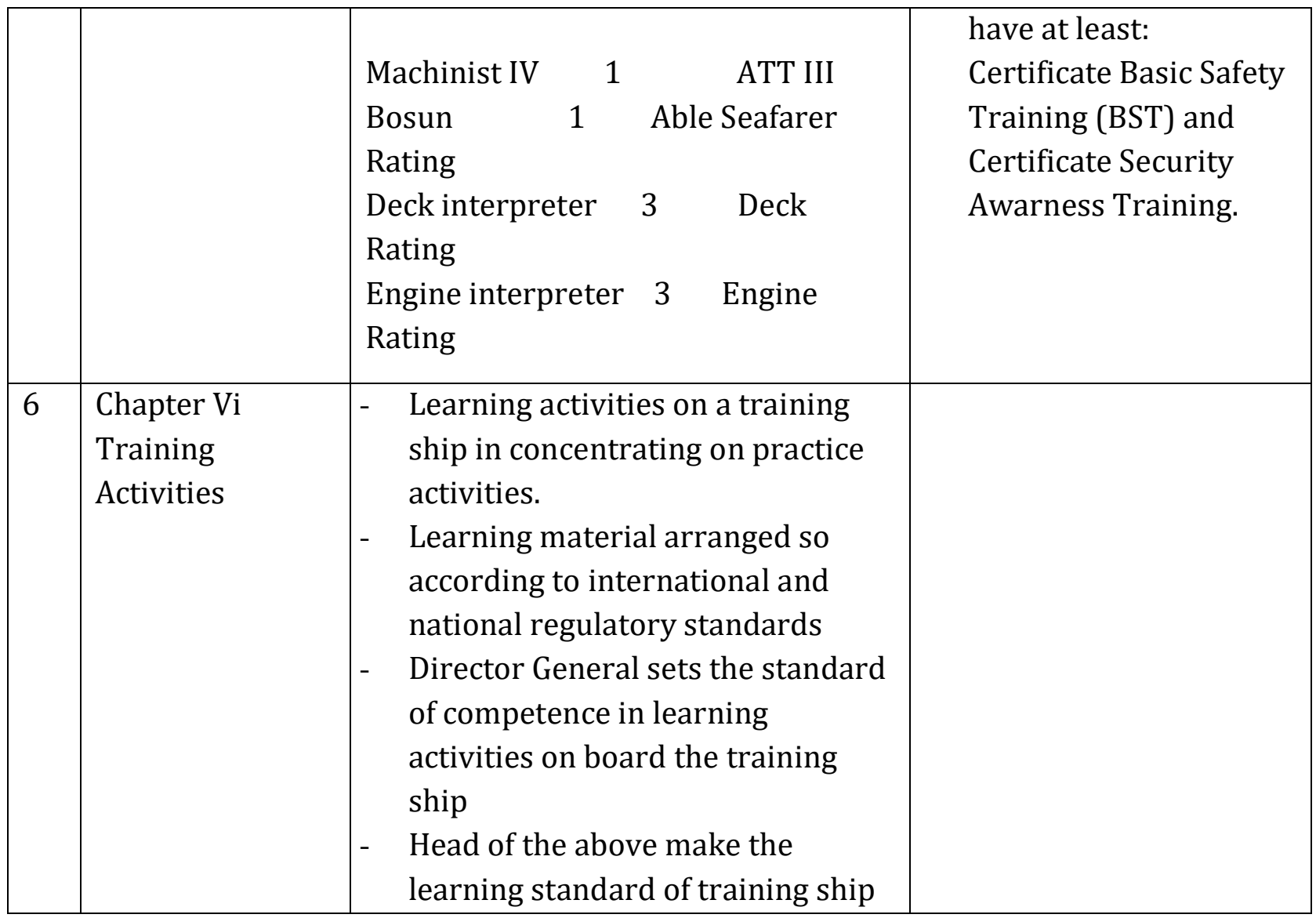

\section{Conclution}

Legal Construction On Training Ship Management Belongs To Human Resources Development Of Transportation (BPSDMP) Based On Dignity Justice Value is urgently needed in view of the existence and operational status of the training ship is not yet clear. These include construction law; General requirements; The arrangement of the training ship; Financing; The learning activities to train merchant vessel performance standards; Manning and training activities training ship. Besides aiming to clarify the existence of regulatory legal training ship construction is expected to also be able to realize justice with dignity for all people both schools (public and private), the public or the government itself.

\section{Bibliography}

[1] Amir, HT., 2007, Pengembangan Program Pelatihan Kerja pada Balai Latihan Kerja Instruktur dan Pengembangan Surabaya. Jurnal Balitbang Jawa timur, cakrawala edition I

[2] Christian K, 2008, Analisa Revitalisasi Balai Latihan Kerja.

[3] Erlinda, 2010, Strategi Pengembangan Balai Latihan Kerja Sumatera Barat. Tesis Pasca Sarjana Universitas Andalas 
[4] Hamalik, Oemar, 2008. Perencanaan Pengajaran Berdasarkan Pendekatan Sistem. Jakarta: Bumi Aksara

[5] Modul Pelatihan Berbasis Kompetensi (2009), Menentukan Tujuan, Prasyarat, dan Materi Pelatihan, Jakarta: Kemenakertrans RI. Lihat juga Modul Pelatihan Berbasis Kompetensi (2009), Merancang Pembuatan Sarana Pendukung Pembelajaran, Jakarta: Kemenakertrans RI

Nofi Erni,Iphov Kumala Sriwana, Debby Karisa (2013) "Peningkatan Kualitas Jasa Pelayanan dengan Metode Servqual dan Quality Function Deployment". Journal Ilmiah Teknik Industri,Vol.1:59-66

Act No. 17 of 1985 on Ratification of the United Nations Convention On The Law of the Sea 1982 (United Nations Convention on the Law of the Sea).

Act No. 17 of 2008 on the Voyage.

Presidential Decree No. 2 of 2015 on RPJMN 2015-2019. 